\title{
Manipulation of television news and its effects on democ- racy
}

\author{
Gönül Cengiz ${ }^{1 *}$, Nevin Arvas ${ }^{2}$ \\ ${ }^{1}$ Departmant of Radio, Television and Cinema, Gaziantep University, Gaziantep, Turkey \\ ${ }^{2}$ Freelance Researcher, Gaziantep, Turkey
}

\section{Keywords \\ Tabloidization \\ Television \\ Watergate affair \\ Bill clinton \\ Iraqi case}

Received: 2 October 2019

Accepted: 5 November 2019

Published: 23 December 2019

\begin{abstract}
This article attempts to examine the role of the politician and the TV as a media form and their effect on society in terms of various cases as instances from the political landscape. By having several assessments on the picked instances with the help of some references, the article aims to critically discuss the citation as "Popularization of politics and tabloidization of TV go hand in hand." Beyond these evaluations, the article aims to reach some consequences related to the effects of this reality on society and opinion forming. The case study method, one of the qualitative research methods, was used to make data analysis of the case studies that constitute the research area. Based on these cases, insights are provided that might help understand the significance of media in media.
\end{abstract}

(C) 2019 The Author(s). Published by TAF Publishing

\section{INTRODUCTION}

Mass media, known as the fourth force today, provide the public with functions such as informing, informing, educating, awareness-raising, socializing, and play an active role in the perception of the system and the transmission of political messages. In today's shrinking world, means of communication strengthens their value. Getting news and having the knowledge of ongoing public issues is one of the main part of the people's daily life not only thanks to growing technology, but also due to increasing demand of people to perceive what is happening around the World (Alamanda, Ramdhani, Kania, Susilawati, \& Hadi, 2019; ElDen, Adikhari, \& Adikhari, 2017; Encabo, 1997). Experience of living in such a world in which media's penetration to life is clearly can be seen; brings us to criticize the media and specifically TV's role on our society. Television has been recognized as one of the most promising areas for conducting long civilian debates. As an information provider, television has been a dominant tool in public communication since the 1960s, which has been on the agenda, encouraging public activity analysts, families or friends to discuss amongst themselves (Keane, 1991; Lawyer, 2017).

\section{METHODOLOGY}

In the contex of this article, it is necessary to find media forms and effect of them on society in terms of various cases. Furthermore, the methodological way is selected as case study, which means it centers on atypical assets and distinctive outcomes as a subjective phenomenon.

With this method, the picked cases help us critically discuss popularization of politics and its effect media and democracy. Media's created images have huge impact to influence people's mind, it is going to be very important to find media's role about on democracy. Therefore, the research question of this study is:

'How do television news create a manipulation about issues and effect on democray?'

\footnotetext{
* corresponding author: Gönül Cengiz

†email: gonulcengiz88@gmail.com
} 
These terms can be discussed around the picked cases, included Bill Clinton, an informal person and who was supported mostly among the young people throughout his precidency. Second case is about 'The Iraqi case' and specifically the news which took place before United States' interference to Iraq. Although United States' tendency to define the 'East and its components' as 'the new other', propaganda of the war had a large place in daily news, like preparing the area for the coming war. With these two cases, this study will focus on the effectiveness of televison news about society's picked instances.

\section{EVALUATION}

Television doesn't tell us what to think, it definitely tells us what to think. Television also does not have to bear the burden of creating a democratic public space only (Chomsky, 2011).

Differing from the other media instruments, TV has a significant role for giving the news not only with sounds but also with the vision. Due to that peculiarity watching TV is accepted as the most objective and easy way to get news; although TV's purity from interest is questionable. There is a common belief that the faith in the news agencies' 'objectivity' is driven by the assumption that pictures are more 'objective' than words." Furthermore, if we focus on the main issues covered on TV, politics can be addressed as a tremendous stage for coverage also to have various interpretations on it, and on its political actors. In this context, television discussion programs have taken place on the screens more intensely in recent years thanks to the democratized media. TV producers, who argue that the most important capacity of television as a communication medium is the capacity to produce a civil mixture between the forms and techniques of popular cultures and ideas related to democratic public negotiation, carefully prepare all the programs in the political context (Hackett, 2006).

In the guidance of such assumptions, issue brings us to face an inevitable coexistence of TV and politics whether it is beneficial or not for public. In addition numerous questions come to mind such as, 'who roles the weak and who roles the omnipotent in this coexistance?' or 'according to which side society shapes its opinions?' moreover 'who gets the reliability and who does not?'. Any intent to respond above mentioned questions, brings a concept as 'tabloidisation' to our research. To have a simple definition, according to some, tabloidisation is a shift by the media away from the real issues to a more 'entertainment' style of journalism that focuses on lifestyle, celebrity, entertainment, crime and scandal. However, that definition can be criti- cised for tabloidisation's containing not only the irreal issues but also the real ones. To examine the term 'tabloidisation' and -specifically the 'tabloidisation of TV'- and its relevance to 'popularisation of politics', I will focus on three instances which are from the political landscape. These three instances are 'Lewinsky Scandal of Bill Clinton', 'Billgate Affair' and the 'Iraqi Case'. Altough all of these are the events proved in some ways that they were real media coverages, while choosing such wellknown events I intented to focus on tabloidisation's amounts wheather it was speculation or was not.

\section{The Concept of Tabloidization in the Context of Televi- sion Relation}

The concept of "tabloidization" is the direct result of the media commercialized by the pressure of advertisers who want to reach large audiences. This concept emerged about a hundred years ago when newspapers began to add sections that emphasize sports and entertainment, drawings and extraordinary appeals to a wider audience (Bal, 2010). One of the shortest definitions of tabloidization was Marvin Kalb, Director of the Center for Political and Public Affairs at the Harvard University Shorenstein Press. According to Kalb, tabloidization is "lowering the value of real news, sexuality and scandalous appreciation" (Esser, 1999).

According to Sparks (1988) definition, info-tainment is one of the binary structure of tabloidization. The first dimension is that with less attention to politics, economy and society, and much more attention to sports, scandals and popular entertainment; it is about paying more attention to the personal, private life of both celebrities and ordinary people, and less attention to political processes, economic and social changes. The information-tainment, which forms the second dimension, is related to the shifting of priorities in the communication tool from news and information to entertainment (Bek, 2004; Sparks, 1988).

Why has tabloidization become one of the main topics of media researchers? What are the reasons for tabloidisation and media consumers turning to such products? It is possible to give different answers to these questions. According to Sparks, the main reason for tabloidization is that in countries where there is a stable bourgeois democracy, political and economic power are separated in the lives of ordinary people. According to him, the more stable and established the bourgeois democracy, the less interested in the functioning of democracy and will turn to more popular political media (Sparks, 1988).

The concept of magazines (Bek, 2004), which means that the popular and tabloid elements of secondary importance 
are placed in the foreground consciously or unconsciously, and that the news content gradually deviates from its real source, sometimes resembling tabloid news media seen in all journalism or even in the entire media. In other words, tabloid journalism is no longer limited to the tabloid press, the environment in which it was born. Today, it is even claimed that television is the primary source of tabloid journalism (Örnebring \& Jönsson, 2004).

The broadening of the news in television means that the importance given to international news, politics and economy is decreasing, while human interest, entertainment, sports, scandal and private life take place more (Bek, 2004).

In the context of violation of private lives, tabloid journalism is one of the most controversial areas of journalism. Although laws are passed to prevent this situation, celebrities' private lives are always the focus of attention of journalists (Aydoğdu \& İlhan, 2018). According to Schutzeneder (2019), the tabloid journalists who pursue sensational news, exaggerated or even fake reporting on celebrities is seen through immediately and punished. After all, viewers do not want to be lied to.

We discuss two important instances in the context of tabloidization in the next sections.

\section{Two Instances of Tabloidisation}

Firstly, about Bill Clinton there can be some comments such as his image was an informal person and who was supported mostly among the young people throughout his precidency. Thanks to the given image as being born in working middle class in public eye, he had comman public base for the votes he had received. Also he was acepted as an educated and intelligent person untill the most powerfull claim about his affairs was carried to news in early January of 1998: 'The president had had an affair!'. This is a brief summary of the wellknown story as it is reflected to TV and viewed by people worldwidely. The president of the United States, Clinton blamed for not only misleading the public, but also misleading his cabinet with assuring them the allegations were untrue. Where was the media in this gloomy picture? And which instruments used by the media to enlighten this scandal? To which direction the attention of the public spotted by the help of coverage? Firstly, instruments of covering that scandal let us to have several perceptions. Although the affair's becoming known in public eye had happened with the help of some telephone records taken by a betraying friend of Lewinsky, also it was illegal, and nobody cared about it. No one questioned the instruments but the fact. That scandal was one of the ranking times in which politics got such rating in TV after the Watergate Affair. And that was satisfactory enough for the media, not to make people ask further questions about its instruments. For causing the first presidential resignation in American history, 'Watergate Affair' had viewed in same curiosity as 'Clinton's scandal', in news, nearly three decades before it. When intruders were caught in Democratic Party Headquarters in June 1972, which had seen as an unoriginal burglary at first. In the early days of the Watergate investigation, the burglary was covered as a simple story without any national importance in most forms of media. Afterwards, Washington Post backed by the New York Times began an inquiry which resulted in President Richard Nixon's resignation, for not being able to survive in front of the judgements such as making secret war, supporting terrorist governments, developing secret agreements to sell weapons to enemy nations (Kalb \& Kalb, 2001).

Media's role in this affair is unquestionably leading for not only enlightening the scandal but also for announcing it world widely. The situation faced can be defined as Pierre Sorlin explains in his book "When something happens the influence of media certainly increases in size. The Watergate hearings, led by the American Congress at the beginning of 1973 forced the newspapers to augment their print runs. Television watching expanded significantly, radio and TV networks were obliged to split to provide extra coverage; hearing were also repeated early in the morning and late in the night.... When it appeared that the interest of the public was not decreasing, radio and TV gave more and more coverage to the Watergate Affair." To have a guess about the limits of over popularisation of politics in this issue is puzzling thanks to the media tools' hyper diffusion of news. However, we can have a guess such as: over popularization of politics which occurs in parallelization with the tabloidization of TV affects the society in numerous ways.

\section{Effects of Tabloidization on Society}

Firstly, considering the situation's social impact on society we can say, tabloidization creates a tremendous mistrust to politicians. In stead of believing in the guidance of the politicians whom they choose, people start to follow the instructions of TV which scarcely takes care of that: "Informing the public about 'events' is not a simple task." In addition, people mostly focus on the issues and the spotted photos of events being unconscious about 'The accuracy of information depends originally on the policy and aims of the news sources.' Few people dig the source of the news in a manner of investigator to perceive pure truths. Generally 'objectivity'-which is an arguable concept - is hidden in the web of coverage. Also, ethically, nobody can force people 
to focus their attention on reaching the 'pure truths', unless 'pure truths' have something attractive to catch their attention (Riordan, 2015).

On the other hand, as happened in the Watergate Affair, purity can be severe sometimes. Thus, policy and the aims of news' sources are undermined in most cases even though it affects you directly in hidden shapes. This is more progressively defined by Chomsky (2011) as: "The people who are able to engineer consent on the ones who have the resources and the power to do it-the business communityand that's who you work for." Secondly, that substitution of politician with TV about opinion forming process of society as a media form; erodes the democracy simultaneously. Unless people shape their opinions in accordance with the thoughts of elected politicians, what is the validity of democracy in life without practice? As "Traditionalist Liberal thought argues that the primary democratic role of the media is to act as a public watchdog overseeing the state." James Curran explains in his article. However the role the media is willing to demonstrate, conflicts with these ideas explained. In stead of supervising the politics as a public watchdog, media interferes into the cases such an actor of them in most cases. As Wieten and Murdock (200) interprets in bit pessimistic but realistic words: "Commercial influence has become much stronger, even (or especially) in broadcasting. People are addressed more as consumers than as citizens" (Wieten \& Murdock, 200).

Also TV-as a media form- with having such anxieties beyond democracy, brings people a kind of democracy which is altered by tabloidisation's taking the place of serious events in most cases. Furthermore, about opinion forming, TV's role is beyond the alteration of democracy as Pierre Sorlin underlines in his work: "This is not just a problem of propaganda: problems are always resented from the point of view of and concepts of the rulers." (Sparks, 1988).

\section{Another Instance: The Iraqi Case}

Diverting from the firstly mentioned two examples, I want to give another case as an instance of tabloidization of TV on a political issue: 'The Iraqi case' and specifically the news which took place before United States' interference to Iraq. Although United States' tendency to define the 'East and its components' as 'the new other', propaganda of the war had a large place in daily news, like preparing the area for the coming war. Consciously or not, every TV channel repeated the speeches of the weapon inspectors of United State, which created an inevitable warn about the Iraq which had been a country experiencing the crucial ruling of a totalitarian leader for decades. Although Iraq had been centre for numerous civilisations and it had been a significant place in the world history, no one pointed this out. Thanks to created tabloids image, not so many people cared about that nearly uncivilised people's lives (Kellner, 2003). Although there had been some opposition to war, they were really unarmed and unfounded in comparison with the US army. To have further interpretations on the issue a reference to Chomsky (2011): "Take the idea of Saddam Hussein is a monster about to conquer the world-widely believedin the United States, and not unrealistically... during the Iran-Iraq war it couldn't defeat Iran without the support of other countries. But all of a sudden it's ready to conquer the world. Did you find anybody who pointed that out?" A consciously focus on the Iraqi Case brings us some clear points such as given organised interpretations of TV as a media form keeps us away from having further reading on issues. Unfortunately, most of the people moves in a social psychology in accordance with what served to them, thus, society stays far away from the questioning 'what is really happening?' unless it is impulsive, scary or harmful to them. In Chomsky (2011) words "The issue is not simply disinformation. The issue is much broader. It's weather we want to live in a free society or weather we want to live under what amounts to form of self-imposed totalitarianism, with the bewildered herd marginalized, directed elsewhere, terrified, screaming patriotic slogans, fearing for their lives and admiring with awe the leader who saved them from destruction, while the educated masses goose-step on command and repeat the slogans they're supposed to repeat and the society dexterities at home. Under such highly imposed thoughts 'bewildered herd' which is more than a group of people having news, never intent to broke the paradigm shaped by media, instead, they pose highly politicized and adversarial behaviour through the items targeted in the news. Beyond misleading that kind of events also alters the democracy by influencing the people's opinions directly. Same scenarios also were viewed in the history. For instance after the Vietnam War, a term occurred to defined the people's avoidance from going into war again called 'Vietnam Syndrome'. Alike the uncomprehending protests to Iraqi War in our age, an alienation through protests indoctrinated, after the Vietnam War, too. People's avoidance named as 'a syndrome' in a totalitarian manner. Chomsky explains the term as: "The Reganite intellectual Norman Pordhoretz defines that as 'the sickly inhibitions against the use of military force' (Chomsky, 2011). People just didn't understand why we should go around torturing people and killing people and carpet bombing them. It was called as the 'Vietnam Syndrome' " 


\section{CONCLUSION}

Whenever politics is popularised some kind of tabloidization fallows it whether it is about the serious issues or not. Although TV tabloidization is the easiest way to catch people's attention to any issue, it has severe side affects on the society. As previously mentioned, people who are guided by the tabloids news, are not able to get the out of the paradigm drawn by TV easily, furthermore, that loads a huge significance to TV about opinion shaping although there are people called politicians who are elected to give clear perspectives to their supporters about politics. TV has an arguable objectivity to be trusted in such pure intentions to this extent. Although it is labelled as one of the major instruments of democracy, I would say its alteration of democracy is in inevitable and in questionable amount. More than serving to politics also to democracy as one of the significant instruments of them, media hampers their growth to a tremendous extend. To conclude, politicians substitute their role with TV on opinion forming and shaping as a media form. Furthermore, its impact on society is really away from being beneficial to policy makers unless they are media bosses.

\section{LIMITATIONS AND RECOMMENDATIONS}

Role of media in society cannot be denied and this study is a small attempt to thoroughly investigate media's influences on the views of general public. However, this field has potential for investigation. Thus, this study must be extended in future.

\section{REFERENCES}

Alamanda, D. T., Ramdhani, A., Kania, I., Susilawati, W., \& Hadi, E. S. (2019). Sentiment analysis using text mining of Indonesia tourism reviews via social media. International Journal of Humanities, Arts and Social Sciences, 5(2), 72-82. doi:https:// doi.org/10.20469/ijhss.5.10004-2

Aydoğdu, A. G., \& İlhan, E. (2018). Etik kavrami çerçevesinde iletişim fakültesi öğrencilerinin magazin medyasina yaklaşimi. Electronic Turkish Studies, 13(18), 45-50.

Bal, E. (2010). Magazination case in television communication: The example of Trt, Ntv and Show Tv. Communication, 4(7), 119-138.

Bek, M. G. (2004). Television journalism and tabloidizing in Turkey. Communication: Researches, 2(1), 9-38. doi:https:// doi.org/10.1501/iltaras_0000000009

Chomsky, N. (2011). Media control: The spectacular achievements of propaganda Canada. New York, NY: Seven Stories Press.

El-Den, J., Adikhari, P., \& Adikhari, P. (2017). Social media in the service of social entrepreneurship: Identifying factors for better services. Journal of Advances in Humanities and Social Sciences, 3(2), 105-114. doi:https://doi.org/10.20474/ jahss-3.2.4

Encabo, M. N. (1997). Gazetecilik not democracy. Medya, Kü Itür, Siyaset, 5(6), 283-298.

Esser, F. (1999). Tabloidization' of news: A comparative analysis of anglo-American and German press journalism. European Journal of Communication, 14(3), 291-324. doi:https://doi.org/10.1177/0267323199014003001

Hackett, R. A. (2006). Is peace journalism possible? Three frameworks for assessing structure and agency in news media. Conflict and Communication Online, 5(2), 1-13.

Kalb, M. L., \& Kalb, M. L. (2001). One scandalous story: Clinton, lewinsky, and thirteen days that tarnished American journalism. New York, NY: Simon and Schuster.

Keane, J. (1991). The media and democracy. Cambridge, UK: Polity Press.

Kellner, D. (2003). From 9/11 to terror war: The dangers of the Bush legacy. LLanham, MY: Rowman \& Littlefield.

Lawyer, L. A. (2017). The changing character of democracy in the pre and post colonial Cameroon: An old practice, a new word. Journal of Advanced Research in Social Sciences and Humanities, 2,(1), 43-53. doi:https://doi.org/10.26500/ jarssh-02-2017-0106

Örnebring, H., \& Jönsson, A. M. (2004). Tabloid journalism and the public sphere: A historical perspective on tabloid journalism. Journalism Studies, 5(3), 283-295. doi:https://doi.org/10.1080/1461670042000246052

Riordan, K. (2015). Accuracy, independence, and impartiality: How legacy media and digital natives approach standards in the digital age. London, UK: Reuters Insitute for the Study of Journalism.

Schutzeneder, J. (2019). Between information, dramatization, and entertainment. Journalism Research, 1(23), 45-50.

Sparks, C. (1988). The popular press and political democracy. Media, Culture \& Society, 10(2), 209-223. doi:https://doi.org/ 10.4324/9781315189772-21

Wieten, J., \& Murdock, P. D. (200). Television across europe: A comparative introduction. London, UK: Sage Publications. 